\title{
Nutritional properties of selected superfood extracts and their potential health benefits
}

\author{
Jacqueline Barsby ${ }^{1,2}$, James Cowley ${ }^{1}$, Shalem Leemaqz ${ }^{2,3}$, Jessica Grieger ${ }^{2,4}$, Daniel McKeating ${ }^{5}$, Anthony Perkins \\ ${ }^{5}$, Susan Elaine Putnam Bastian ${ }^{1}$, Rachel A Burton ${ }^{1}$, Tina Bianco-Miotto ${ }^{\text {Corresp. } 1,2}$ \\ ${ }^{1}$ Waite Research Institute and School of Agriculture, Food and Wine, University of Adelaide, Adelaide, SA, Australia \\ 2 Robinson Research Institute, University of Adelaide, Adelaide, SA, Australia \\ ${ }^{3}$ College of Medicine and Public Health, Flinders University of South Australia, Bedford Park, SA, Australia \\ 4 Adelaide Medical School, University of Adelaide, Adelaide, SA, Australia \\ 5 School of Medical Science, Griffith University, Southport, QLD, Australia \\ Corresponding Author: Tina Bianco-Miotto \\ Email address: tina.bianco@adelaide.edu.au
}

Background. The term 'superfoods' is used to market foods considered to have significant health benefits. 'Superfoods' are claimed to prevent diseases as well as improving overall health, though the lack of explicit criteria means that any food can be labelled 'super' without support from scientific research. Typically, these 'superfoods' are rich in a particular nutrient for example antioxidants or omega-3 fatty acids. The objective of this study was to investigate the nutritional properties of a selection of superfood seeds: flax, chia, hulled sunflower and two types of processed hemp seeds and determine whether they may have potential health benefits. Methods. We developed a simple aqueous extraction method for ground seeds and analysed their composition by mineral, protein and monosaccharide analyses. Cell viability assays were performed on Caco-2 and IEC-6 intestinal epithelial cells using increasing doses of the prepared extracts. Results. Increased cell viability was observed in both cell lines with increasing concentrations of the flax seed, chia seed or hulled sunflower extracts $(P<0.05)$. Compositional analyses revealed the presence of polysaccharides, proteins and essential minerals in the aqueous extracts and in vitro assays showed sunflower had the highest antioxidant activity. However, differences in extract composition and antioxidant properties could not be directly related to the observed increase in cell viability suggesting that other components in the extracts may be responsible. Future studies will further characterize these extracts and investigate whether they are beneficial for gastrointestinal health. 
1 Nutritional Properties of Selected Superfood Extracts and Their Potential Health Benefits

2

3 Jacqueline P. Barsby ${ }^{1,2}$, James M. Cowley ${ }^{1}$, Shalem Y. Leemaqz ${ }^{2,3}$, Jessica A. Grieger ${ }^{2,4}$, Daniel R.

4 McKeating $^{5}$, Anthony V. Perkins ${ }^{5}$, Susan E.P. Bastian ${ }^{1}$, Rachel A. Burton ${ }^{1}$, Tina Bianco-Miotto ${ }^{1,2}$.

5

$6 \quad{ }^{1}$ Waite Research Institute and School of Agriculture, Food and Wine, University of

7 Adelaide, South Australia, 5005, Australia

$8{ }^{2}$ Robinson Research Institute, University of Adelaide, South Australia, 5005, Australia

$9{ }^{3}$ College of Medicine and Public Health, Flinders University, Bedford Park, South Australia, 10 5042, Australia

$11{ }^{4}$ Adelaide Medical School, University of Adelaide, South Australia, 5005, Australia

125 School of Medical Science, Griffith University, Gold Coast Campus, Parklands Drive,

13 Southport, Queensland 9726, Australia

15 Corresponding Author:

16 Tina Bianco-Miotto

17 Waite Research Institute and School of Agriculture, Food and Wine, University of

18 Adelaide, South Australia, 5005, Australia

19 Email address: tina.bianco@adelaide.edu.au

20

21

22

23

24 


\section{Abstract}

26 Background. The term 'superfoods' is used to market foods considered to have significant

27 health benefits. 'Superfoods' are claimed to prevent diseases as well as improving overall health,

28 though the lack of explicit criteria means that any food can be labelled 'super' without support

29 from scientific research. Typically, these 'superfoods' are rich in a particular nutrient for

30 example antioxidants or omega-3 fatty acids. The objective of this study was to investigate the

31 nutritional properties of a selection of superfood seeds: flax, chia, hulled sunflower and two

32 types of processed hemp seeds and determine whether they may have potential health benefits.

33 Methods. We developed a simple aqueous extraction method for ground seeds and analysed

34 their composition by mineral, protein and monosaccharide analyses. Cell viability assays were

35 performed on Caco-2 and IEC-6 intestinal epithelial cells using increasing doses of the prepared

36 extracts. Results. Increased cell viability was observed in both cell lines with increasing

37 concentrations of the flax seed, chia seed or hulled sunflower extracts $(\mathrm{P}<0.05)$. Compositional

analyses revealed the presence of polysaccharides, proteins and essential minerals in the aqueous

extracts and in vitro assays showed sunflower had the highest antioxidant activity. However,

differences in extract composition and antioxidant properties could not be directly related to the

observed increase in cell viability suggesting that other components in the extracts may be are beneficial for gastrointestinal health. 


\section{Introduction}

52 Nearly 40 years ago, functional foods were idealized as a concept in which foods could

53 beneficially affect one or more targeted functions in the body, beyond adequate nutritional

54 effects (1999). Although different definitions exist, a common characteristic is that, compared

55 with regular foods, functional foods have beneficial physiological effects and/ or reduce the risk

56 for disease development due to the addition, or removal of certain nutrients (Arai 2002). More

57 recently, the term "superfoods" has been introduced to describe foods with specific health

58 benefits. They are widely reported on in the media, but with no generally accepted definition,

59 any food can be labelled as such (Proestos 2018). Foods including flax, hemp, chia and

60 sunflower seeds (botanically hemp, chia and sunflower seeds are nutlets), have all been

61 described as superfoods (van den Driessche et al. 2018) however, there is a paucity of literature

62 on their health benefits.

63 Flax (Linum usitatissimum) seeds and chia (Salvia hispanica) seeds have high levels of omega-3

64 fatty acids (Goyal et al. 2014; Ixtaina et al. 2011), whereas hemp (Cannabis sativa) and

65 sunflower (Helianthus annuus) seeds have greater amounts of omega-6 fatty acids (Callaway

66 2004). These superfoods are claimed, by the media, to have a large range of health benefits, but

67 they are typically not supported by scientific evidence (Oude Groeniger et al. 2017). Like other

68 seeds, hemp seed foods are claimed to be good sources of protein, dietary fibre and omega-3

69 fatty acids. However, the sale of hemp seed foods has historically been prohibited in Australia

70 due to legal issues concerning the psychoactivity of tetrahydrocannabinol (THC) in some strains

71 of Cannabis. Subsequent changes to the Australia New Zealand Food Standards Code (Food

72 Standards Australia New Zealand) in November 2017 legally permitted sale of foods containing

73 industrial hemp ingredients with THC levels of less than $1 \%$, to the general public. 
74 In pre-clinical studies, flax seed reduced the level of intracellular reactive oxygen species and 75 protected genomic DNA against damage in V79 Chinese hamster pulmonary fibroblasts

76 (Skorkowska-Telichowska et al. 2016). In diet-induced obese rats, chia seed oil demonstrated 77 anti-inflammatory effects which reduced the severity of rheumatoid arthritis (Mohamed et al. 78 2020). Ingested chia seed and chia seed oil have been shown to improve systemic glucose and 79 insulin tolerance in rats (Marineli Rda et al. 2015). A recent review of sunflower seeds, 80 summarised the content of nutrients, minerals, antioxidants and vitamins, and their roles in 81 antioxidant, antimicrobial, antidiabetic, antihypertensive, anti-inflammatory and wound-healing 82 effects (Guo et al. 2017; van den Driessche et al. 2018). There has been limited literature on

83 hemp seeds in food products, but the field is rapidly expanding and promising, with current 84 research showing beneficial effects on human health (Farinon et al. 2020).

85 Previous in vitro extraction methods for seed constituents have typically used very high 86 temperatures and harsh solvents like ethanol and methanol (Butt et al. 2019). Although these 87 methods yield a high concentration of bioactive compounds, they may not necessarily replicate 88 what can be extracted by the human body after ingestion of these superfoods, and may heavily 89 over-represent cytotoxic compounds in the extract that are typically poorly-accessible to the digestive system (Alminger et al. 2014; Bohn et al. 2018; Minekus et al. 2014). By creating a

91 new extraction method without the use of harsh solvents or high temperatures we can eliminate 92 some of the cytotoxic compounds and also have a better replication of what the human body 93 would be able to extract and use.

94 The objective of this study was to develop a mild aqueous extraction method, performed at

95 human body temperature, which may better mimic what could be extracted from 'superfood' 96 seeds when ingested. This extraction generated the products flax seed extract (FSE), chia seed 
97 extract (CSE), hulled sunflower extract (HSE), hulled hemp extract where just the hemp hearts

98 are used (HHE) and hemp flour extract (HFE). This study investigated the nutrient composition

99 of these extracts, and the impact on cell growth by in vitro cell viability assays on IEC-6 and

100 Caco-2 intestinal epithelial cells, the most commonly used cell lines for testing novel food

101 products (Sambruy et al. 2001). In addition, we profiled the nutritional composition of these seed

102 extracts and the flours they were derived from.

103

104

\section{Materials \& Methods}

105

106

Materials

107 Chia (Organic Road, Australia), flax (Lotus, Australia), hulled sunflower seeds (Natural Road,

108 Australia) and hulled hemp seeds (Hemp Foods Australia, Australia) were purchased

109 commercially. A pre-ground and processed commercial hemp flour (Hemp Foods Australia) was

110 also purchased, this flour was made from whole hemp seed with the oil pressed out and some of

111 the protein extracted

112 Flour Preparation

113 Approximately 1 cup of seeds were ground using a blade mill-type Multi Grinder (Sunbeam,

114 Australia) for approximately 5 minutes at room temperature to create a seed meal. The meal was

115 sieved and larger pieces were ground again. This flour was sealed in a falcon tube and placed in

116 a sealed container in the fridge with silica beads to prevent excess moisture. .

117 Seed and Flour Nutritional Profile

118 Where relevant nutritional information, such as protein, energy $(\mathrm{kJ})$, fat, dietary fibre and

119 carbohydrate contents were taken from the commercial packaging of the purchased seeds. Lipid

120 content and fatty acid profiles of flours were determined by the Waite Lipid Analysis Service, at

121 the South Australian Health and Medical Research Institute (Liu et al. 2014). Total lipid in whole 
122 seed flour was determined by modified (Folch et al. 1957) and fatty acid profiles were

123 determined by gas chromatography of transesterified lipids following (Liu et al. 2014).

124 Crude Aqueous Body Temperature Seed Extracts

125 To generate a crude aqueous body temperature extract, $4 \mathrm{~g}$ of flour was added to $200 \mathrm{~mL}$ of $\mathrm{RO}$

126 (reverse osmosis) water at $37^{\circ} \mathrm{C}$ in a borosilicate glass beaker and the mixture was left to agitate

127 on a heated magnetic stirrer to maintain this temperature. After 3 hours, the mixture was

128 transferred into $50 \mathrm{~mL}$ polypropylene tubes and centrifuged at $1000 \mathrm{rpm}(200 \mathrm{x} \mathrm{g})$ for 10 minutes

129 to pellet any debris. The supernatant was removed and freeze dried to a constant weight using a

130 Freezone 6 freeze dry system (Labconco, US). Yield of extract was determined as the percentage

131 of freeze-dried extract mass to mass of flour (Figure 1). Freeze dried extracts were dissolved in

132 sterile PBS (Life Technologies ${ }^{\mathrm{TM}}$ ) at a concentration of $5 \mathrm{mg} / \mathrm{mL}$ for cell culture experiments and

133 sterile RO water for compositional analysis.

134 IEC-6 and Caco-2 Cell Culture

135 IEC-6 (CRL1592) and Caco-2 (HTB-37) cells originally purchased from the ATCC were

136 provided by SEPB and cultured in Gibco ${ }^{\circledR}$ Dulbecco's Modified Eagle Medium (DMEM; Life

137 Technologies ${ }^{\mathrm{TM}}$ ) with 10\% Fetal Bovine Serum (FBS; Sigma), antibiotic/antimycotic solution

138 (10,000 units penicillin, $10 \mathrm{mg}$ streptomycin and $25 \mu \mathrm{g}$ amphotericin B per $\mathrm{mL}$ ) (Sigma). The

139 cells were maintained in a $37{ }^{\circ} \mathrm{C}$ incubator with $5 \% \mathrm{CO}_{2}$ in $75 \mathrm{~cm}^{2}$ flasks (Greiner bio-one) and

140 the media was changed every 72 hours. Cells were passaged at $70-80 \%$ confluency and split at a

141 1:3 ratio using Trypsin $\left(\right.$ Gibco $\left.^{\circledR}\right)$ to dissociate the cells from the flask surface. Cells were stained

142 with trypan blue $\left(\right.$ Gibco $\left.{ }^{\circledR}\right)$ and counted using a haemocytometer on an Olympus inverted

143 microscope.

144 Cell Viability Assay 
145 A dose-response cell viability assay was performed as per Kumar et. al (Kumar et al. 2018).

146 IEC-6 or Caco-2 cells (Sambruy et al. 2001) were plated in 96 well plates at a concentration of

$1471 \times 10^{5}$ cells/well in $50 \mu \mathrm{L}$ of DMEM with $10 \% \mathrm{FBS}$, then left for 24 hours to adhere. Extracts $(5$

$148 \mathrm{mg} / \mathrm{mL}$ in PBS) were diluted in DMEM with $10 \% \mathrm{FBS}$ to $1 \mathrm{mg} / \mathrm{mL}$ and then two-fold serial

149 dilutions were prepared (resulting in concentrations of $1 \mathrm{mg} / \mathrm{mL}, 0.5 \mathrm{mg} / \mathrm{mL}, 0.25 \mathrm{mg} / \mathrm{mL}, 0.125$

$150 \mathrm{mg} / \mathrm{mL}, 0.0625 \mathrm{mg} / \mathrm{mL}$ and a vehicle control, $0 \mathrm{mg} / \mathrm{mL})$. The extract treatments $(50 \mu \mathrm{L})$ were

151 applied to triplicate wells, and the plate was left to incubate for another 24 hours. MTT solution

152 (Invitrogen) was diluted with PBS to $1 \mathrm{mg} / \mathrm{mL}$, filter sterilized and $50 \mu \mathrm{L}$ was added to every

153 well using a multichannel pipette and the plate was incubated for 4 hours at room temperature. A

$154100 \mu \mathrm{L}$ volume of dimethyl sulfoxide (DMSO; Sigma-Aldrich) was added to every well, the

155 plate was covered in aluminium foil and agitated on a plate shaker for 15 minutes to extract the

156 formazan product. Absorbance was read using a Thermo Multiskan Spectrum spectrophotometer

157 at $570 \mathrm{~nm}$. The results were converted into a percentage by comparing them to the vehicle

158 control value:

159

$$
\text { Cell viability }(\%)=\frac{a b s 570(\text { sample })}{a b s 570(\text { control })} * 100
$$

160 Each cell viability assay was repeated to obtain 3-4 independent experiments per cell line.

161 Extract Characterisation

162 Protein Content

163 A Qubit Fluorometric Protein Assay Kit (Invitrogen, USA) was used to determine the protein

164 content of the crude aqueous extracts $(1 \mathrm{mg} / \mathrm{mL})$, in triplicate, as per the manufacturer's

165 instructions.

166 Monosaccharide Analysis 
167 Monosaccharide analysis was performed in duplicate and determined using reverse phase high

168 performance liquid chromatography (RP-HPLC) of 1-phenyl-3-methyl-5-pyrazoline (PMP)

169 derivatives prepared following Hassan et al. with modifications listed in Cowley et al. (Cowley

170 et al. 2020; Hassan et al. 2017). Quantification was performed using the area under the peaks

171 compared to standard curves of D-mannose, D-ribose, L-rhamnose, D-glucuronic acid, D-

172 galacturonic acid, D-glucose, D-galactose, D-xylose, L-arabinose and L-fucose.

173 Mineral Content

174 Ultra-trace element analysis of freeze-dried extracts and their source flour was determined by

175 inductively coupled plasma-mass spectrometry (ICP-MS) following (Hofstee et al. 2019;

176 McKeating et al. 2020) as a fee-for-service by the Perkins Pregnancy Research Laboratory

177 (Griffith University, Australia). All runs were spiked with ${ }^{45} \mathrm{Sc},{ }^{89} \mathrm{Y},{ }^{115} \mathrm{In},{ }^{159} \mathrm{~Tb}$ internal

178 standards to ensure recovery and a calibration standard set was run before sample analysis. A

179 spiked quality control run was performed after every 6 samples followed by a wash step. Data

180 presented are the average of 2 technical repeats with minimal error. Mineral extractability was

181 estimated using the following equation:

182

$$
\text { Extractability }(\%)=\frac{\left(C^{F} \times M^{F}\right)}{\left(C^{E} \times M^{E}\right)} \times 100
$$

183 Where $\mathrm{C}^{\mathrm{F}}$ and $\mathrm{C}^{\mathrm{E}}$ refer to the mineral concentration in $\mathrm{mg} / \mathrm{kg}$ in source flour and extract,

184 respectively, and $\mathrm{M}^{\mathrm{F}}$ and $\mathrm{M}^{\mathrm{E}}$ refer to the mass in grams of flour used for extraction and

185 recovered extract respectively.

186 Ferric Reducing Antioxidant Power (FRAP) Assay

187 A FRAP assay was performed in triplicate as per Benzie and Strain (Benzie \& Strain 1996).

188 Each of the crude aqueous seed extracts were serially diluted using dimethyl sulfoxide (DMSO;

189 Sigma-Aldrich) at 1:2 dilution, 8 times, with a starting concentration of $1 \mathrm{mg} / \mathrm{mL}$. The ascorbic 
190 acid control was also diluted in the same manner. A ferrous sulphate solution was diluted using 191 milli-Q water at concentrations of $0,0.1,0.2,0.4,0.5,0.6,0.8$ and $1 \mathrm{mM}$. A $15 \mu \mathrm{L}$ aliquot of 192 each of the extract samples were added at multiple concentrations in a 96 well plate. A $15 \mu \mathrm{L}$ 193 volume of the FRAP reagent containing acetate buffer, TPTZ (2,4,6-Tris(2-pyridyl)-s-triazine) 194 and $\mathrm{FeCl}_{3}$ (iron (III) chloride) were added to every well and the results were read on a 195 spectrophotometer at $570 \mathrm{~nm}$.

196 Statistical Analysis

197 Where applicable, statistical differences in extract composition were determined by ANOVA 198 with a post-hoc Tukey's Honestly Significant Difference (HSD) test in GenStat $15^{\text {th }}$ Edition. 199 For MTT assays, marginal models for viability were fitted using Generalized Estimating 200 Equations using R version 3.6.3 (R Foundation for Statistical Computing, Vienna, Austria), 201 accounting for repeated experiments assuming an independence working correlation structure.

202 Cubic splines were used to explore the non-linear dose-response relationship of concentration on 203 viability. Separate marginal models were fitted with categorical concentrations to allow for 204 comparisons to the DMEM+FCS (vehicle) group.

\section{Results}

206 Fatty acid and micronutrient analyses of ground flours

207 Prior to preparing extracts for cell treatment, the seeds were ground into a flour. Tests on the

208 flour indicated that they all contain beneficial and essential micronutrients including magnesium, 209 calcium, iron and zinc (Table 1). Flax seed flour had the highest content of omega-3 fatty acids 210 in comparison to omega 6 at a ratio of 11:3, followed by chia flour at 3:1 (Table 1).

211 Comparatively, hulled hemp seed flour, processed hemp flour and sunflower seed flour all had

212 higher levels of omega-6 compared to omega-3; sunflower flour had the highest ratio (1:614 of 213 omega-3:omega-6). Chia seeds showed a significantly higher amount of carbohydrates (37\%) in 
214 comparison to the other seeds (Table 1). Hemp flour had the highest level of dietary fibre (67\%),

215 followed by chia (35\%) then flax (29\%). Sunflower had the highest total fat content (57\%),

216 followed by hemp seed (54\%), flax (43\%), and chia (29\%), with hemp flour being the lowest

$217(9 \%)($ Table 1).

218 All seeds contained magnesium with hulled hemp seeds having the highest level (5359 mg/kg),

219 followed by flax (4425 mg/kg), while chia, sunflower and hemp flour had slightly lower levels

220 (3296-3525 mg/kg). Both the hulled hemp seed and hemp flour contained the highest levels of

221 iron $(196 \mathrm{mg} / \mathrm{kg})$ compared to the other seeds $(80-145 \mathrm{mg} / \mathrm{kg})$. Hulled hemp seed had the highest

222 level of zinc, followed by hulled sunflower, hemp flour and chia, with flax having the lowest

223 level of zinc (Table 1). Only flax seed had detectable levels of sodium at $1073 \mathrm{mg} / \mathrm{kg}$ compared

224 to the other seeds. Chromium, cobalt, selenium and molybdenum were present in very low levels

225 or not detectable.

\section{Aqueous seed extract composition}

227 To produce material that could be used for treating the cells, aqueous extracts FSE, CSE, HSE,

228 HHE and HFE were generated from flax seed, chia seed, hulled sunflower, hulled hemp and

229 hemp flour, respectively (Figure 1). The same method was used on each seed yet varying

230 amounts of extractable material were produced. Yield was highest for FSE at 39.46\%, followed

231 by $\mathrm{HHE}$ at $32.34 \%$, HSE at $25.06 \%, \mathrm{CSE}$ at $16.28 \%$ and lastly $\mathrm{HFE}$ at $8.06 \%$. These numbers

232 were calculated by comparing the initial weight ( $4 \mathrm{~g})$ with the freeze-dried weight of the aqueous

233 extract.

234 MTT cell viability assays

235 Both cell lines showed a similar response to each of the seed extracts (Figures 2 and 3,

236 Supplementary Figures 2 and 3). Caco-2 and IEC-6 cell viability showed little change when 
237 treated with HHE or HFE when compared to the vehicle control (Figures 2 and 3). FSE resulted

238 in the largest increase in cell viability in both Caco-2 and IEC-6 cells (at the highest dose, 1

$239 \mathrm{mg} / \mathrm{mL}, 163 \%$ and $195 \%$ of the vehicle control respectively) (Figures 2 and 3).

240 Protein and monosaccharide analyses

241 Analyses were performed to determine the protein and monosaccharide content of each crude

242 aqueous seed flour extract. The protein analysis showed FSE had the highest levels of protein,

243 followed by CSE when measured in the body temperature water extracts (Figure 4). These levels

244 differed slightly from the commercial label, which was based on the whole seed prior to

245 extraction (Table 1). Flax, chia and hulled sunflower seed all originally had the same amount of

246 protein per gram, however post-extraction, different levels were observed, with FSE having the

247 highest protein content of $20.62 \pm 1.28(\% \mathrm{w} / \mathrm{w})$ and HSE having the lowest content of 7.60 \pm 0.15

$248(\% \mathrm{w} / \mathrm{w})$ (Figure 4). A monosaccharide analysis was performed which showed the presence of

249 key polysaccharide building block monosaccharides, in varying concentrations between extracts

250 (Figure 4). CSE and FSE had the characteristic monosaccharides found in the mucilage fraction

251 of each seed type. HSE, HFE and HHE extracts showed high levels of glucose but limited levels

252 of the other monosaccharides quantified (Figure 4).

253 Mineral analysis of the aqueous extracts

254 Essential minerals were tested both pre- and post- extraction as this allowed for comparison of

255 the availability of each mineral. The results showed high variability for each extract for the

256 minerals measured (Figure 5). For minerals such as potassium, chromium, selenium, iodine and

257 copper, there was a slight increase in concentration from the flour to the extract from every seed.

258 Sodium was only present in flax seed, with a 3-fold increase in concentration in the extract.

259 Hulled hemp and chia seed showed a similar level of magnesium in both the flour and 
260 corresponding extract, with the concentration increasing in the extract. The levels of magnesium

261 were relatively similar in flax seed, hemp flour and hulled sunflower and did not change

262 significantly in the extracts. Flax seed showed consistent iron levels in both the flour and the

263 extract, hulled sunflower showed a slight increase in the extract and chia seed, hulled hemp and

264 hemp flour showed a slight decrease (Figure 5). Chia seed had higher levels of calcium in the

265 flour sample, but there was a decrease in the extract. Manganese showed a substantial increase in 266 concentration in the extract for hemp flour only. Cobalt was enriched in the extracts from flax

267 seed and chia seed compared to the initial flour sample. Nickel showed an initial high

268 concentration in hulled hemp but was almost entirely absent in the extract.

269 Extract composition

270 The protein, monosaccharide and mineral analyses were combined and compared for the total

271 extracted material (Figure 4). This figure shows that even with the combined protein,

272 carbohydrates and minerals content quantified, there was still over $50 \%$ of the aqueous extract

273 which was not categorised. The extract composition of FSE and HSE is predominantly protein,

274 while for HFE it is carbohydrates. For CSE and HHE, more than $75 \%$ of the extract is currently 275 uncharacterised.

276 Antioxidant capacity of body temperature extracts

277 The antioxidant capacity of each of the seed extracts was determined using a ferric reducing 278 antioxidant power (FRAP) assay (Supplementary Figure 1). HFE and HHE extracts had 279 particularly low antioxidant capacity, while FSE and CSE showed a slight but significantly 280 higher antioxidant capacity $(\mathrm{p}<0.05)$. HSE showed the highest antioxidant capacity of all the 281 extracts. 


\section{Discussion}

284

285 Many seeds and plant products are declared to be superfoods, with multiple health benefits that 286 often have little scientific evidence to support the claims. This study investigated the nutritional 287 properties of both flour and flour extracts from several popular 'superfood' seeds, as well as the 288 effects these extracts had on Caco-2 and IEC-6 cell viability. This provides us with evidence that 289 these 'superfood' seed extracts may have gastrointestinal health benefits, derived from their 290 ability to enhance cell viability of intestinal epithelial cells, as well as the beneficial nutritional 291 profiles of the extracts. Seed extracts were made using a mild aqueous extraction method then 292 properties such as mineral and carbohydrate content, protein content, and antioxidant capabilities 293 were tested.

294 Techniques for producing botanical extracts are typically solvent-reliant (e.g. hydroalcoholic) 295 and often use high temperature/pressure to obtain high yields of often lowly-abundant bioactive 296 compounds (Santana \& Macedo 2019; Zimmer et al. 2021). While these techniques are efficient, 297 they likely over-extract and over-represent cytotoxic compounds in the extracts which may make 298 them not ideal for assessing the health-promoting activities of botanical materials (Alminger et 299 al. 2014; Bohn et al. 2018; Minekus et al. 2014). To produce a more biologically-relevant extract 300 for such testing, we developed a simple, yet novel, aqueous extraction method performed at 301 human body temperature $\left(37^{\circ} \mathrm{C}\right)$ to isolate water-extractable constituents from five 'superfoods' 302 derived from seeds (Figure 1). This method successfully produced crude aqueous extracts from 303 flax, chia, hulled sunflower and hulled hemp seeds as well as hemp flour, hereafter referred to as 304 FSE, CSE, HSE, HHE, and HFE, respectively. This extraction method is not perfect and ideally

305 future experiments would use an in vitro extraction method that more closely mimics the 306 digestive system. This would likely give results more reflective of what would be obtained from 
307 ingestion of these seeds and flours as it includes gut digestion enzymes and multiple $\mathrm{pH}$ changes,

308 providing a better indication of what the body is able to extract from ingested seeds (Glahn et al.

309 1998).

310 It is likely that the extraction conditions were not suitable for polysaccharide mobilisation from

311 the cell walls of the different tissues of all seeds tested, as in flax and chia extracts, so

312 monosaccharides characteristic of highly water-soluble mucilage were most of what was

313 detected (Lin et al. 1994; Naran et al. 2008). It is also possible that there are insoluble and acid

314 hydrolysis-resistant carbohydrates present that are not quantifiable by the monosaccharide

315 profiling method used here. Therefore, different methods could be tested to increase

316 quantification recovery of polysaccharides such as by Saeman's hydrolysis (Saeman 1945) or

317 more sophisticated saccharide profiling could be employed like methylation linkage analysis

318 (Pettolino et al. 2012).

319 To provide an indication of any health benefits/toxicity of the 'superfood' extracts, increasing 320 doses were applied to IEC-6 rat small intestine and Caco-2 (Figures 2 and 3) human large

321 intestine epithelial cells grown in vitro, after which cell viability was measured (Ponce de Leon-

322 Rodriguez et al. 2019). Using non-linear models, the relationship between extract dose and cell

323 viability was studied, showing that even at the highest dose, $1 \mathrm{mg} / \mathrm{mL}$, no extract showed

324 significant cytotoxic effects. Several concentrations of flax, chia and sunflower extracts were

325 found to increase the viability of IEC-6 and Caco- 2 cells. FSE showed the greatest change with

326 approximately $195 \%$ increase in viability at the highest concentration measured $(1 \mathrm{mg} / \mathrm{mL})$,

327 followed by CSE and HSE, at approximately 140\% and 115\% respectively. The HHE and HFE

328 maintained a consistent level of viability with no significant changes. 
329 The MTT cell viability assay used here is essentially a measure of cellular metabolic activity,

330 and thus the increases in cell viability observed are either a result of a decrease in apoptosis

331 and/or an increase in proliferation. Extracts observed to enhance IEC-6 and Caco- 2 cell viability

332 likely contain several components that decrease apoptosis or increase cell proliferation including

333 multiple beneficial micronutrients and antioxidant capabilities. FSE were enriched in sodium,

334 chromium, cobalt, copper, selenium, and iodine and had a high protein content and antioxidant

335 capabilities (Figure 4). Studies have indicated that an increase in antioxidant activity can reduce

336 apoptosis in healthy cells, which would result in a higher cell viability count (Takahashi et al.

337 2013; Xu et al. 2012).

338 A key factor preventing apoptosis in cells is the protection against oxidative stress, which can be

339 prevented in the human body by antioxidants (Aruoma 1998; Maritim et al. 2003). The FRAP

340 assay used to measure antioxidant activity (Supplementary Figure 1) did show that FSE, CSE

341 and HSE had the highest antioxidant capabilities, however they did not directly match the

342 increase in cell viability, as HSE had significantly higher antioxidant capabilities than both FSE

343 and CSE. The HSE antioxidant activity was measured between those reported for Ribes nigrum

344 (blackcurrant) buds and Coffea Arabica (arabica coffee) seeds (Dudonne et al. 2009). Although

345 FRAP was the only method used in this study, other methods such as a DPPH (2,2-diphenyl-1-

346 picryl-hydrazyl-hydrate) assay or an ABTS (2,2'-azino-bis(3-ethylbenzothiazoline-6-sulfonic

347 acid) could also be used to measure different antioxidant capabilities (Shah \& Modi 2015). It is

348 also possible that antioxidants combined with other factors could result in the increased cell

349 viability observed (Knight 2000). However, as oxidative stress was not specifically induced in

350 this study this is difficult to include and it is likely that other mechanisms are also involved. 


\section{Conclusions}

354 The aim of this study was to determine whether superfood seeds have potential health benefits.

355 To achieve this we developed a simple method for generating seed extracts with conditions that 356 more closely mimics human physiology. We found an increase in cell viability of both the Caco-

3572 and IEC-6 cells with increasing amounts of flax, chia and hulled sunflower extracts. Whilst the

358 extraction method used was beneficial for this study in decreasing the risk of alcohols

359 contaminating and degrading the extracts, future experiments could explore an in vitro extraction

360 method, using gut digestion enzymes and multiple $\mathrm{pH}$ changes to continue to improve the

361 biologically-relevant extraction of 'superfood' constituents.

362 Further research is needed to fully investigate the mechanisms by which some of the extracts

363 increased cell viability including cell proliferation, oxidative stress, and/or inflammation

364 pathway changes. In addition, other models can be used to investigate the potential health

365 benefits of these superfood seeds and in particular whether gut health is improved. The

366 microbiome could also be explored since this is crucial for optimal gut health. This research

367 highlights that 'superfoods' may indeed have some of the health-promoting activities they are

368 lauded for and the techniques used here, a simple aqueous extraction technique and the treatment

369 of gastrointestinal cells in vitro, may provide simple methods to begin to provide evidence of 370 clinical benefits.

371

\section{Acknowledgements}

373

374 The authors want to express their gratitude to Sandy Khor and Anh Ngoc Hoang Nguyen for 375 their assistance in cell culturing and monosaccharide analysis. 


\section{References}

379 1999. Scientific concepts of functional foods in Europe. Consensus document. Br J Nutr 81

380

381

382

383

384

385

386

387

388

389

390

391

392

393

394

395

396

397

398

399

400

401

402

403

404

405

406

407

408

409

410

411

412

413

414

415

416

417

418

419

420

421

422

423

424

425

426

427 Suppl 1:S1-27.

Alminger M, Aura AM, Bohn T, Dufour C, EI SN, Gomes A, Karakaya S, Martinez-Cuesta MC, McDougall GJ, Requena T, and Santos CN. 2014. In Vitro Models for Studying Secondary Plant Metabolite Digestion and Bioaccessibility. Compr Rev Food Sci Food Saf 13:413-436. 10.1111/1541-4337.12081

Arai S. 2002. Global view on functional foods: Asian perspectives. Br J Nutr 88 Suppl 2:S139143. https://doi.org/10.1079/BJN2002678

Aruoma OI. 1998. Free radicals, oxidative stress, and antioxidants in human health and disease. J Am Oil Chem Soc 75:199-212. https://doi.org/10.1007/s11746-998-0032-9

Benzie IF, and Strain JJ. 1996. The ferric reducing ability of plasma (FRAP) as a measure of "antioxidant power": the FRAP assay. Anal Biochem 239:70-76. https://doi.org/10.1006/abio.1996.0292

Bohn T, Carriere F, Day L, Deglaire A, Egger L, Freitas D, Golding M, Le Feunteun S, Macierzanka A, Menard O, Miralles B, Moscovici A, Portmann R, Recio I, Remond D, Sante-Lhoutelier V, Wooster TJ, Lesmes U, Mackie AR, and Dupont D. 2018.

Correlation between in vitro and in vivo data on food digestion. What can we predict with static in vitro digestion models? Crit Rev Food Sci Nutr 58:2239-2261. 10.1080/10408398.2017.1315362

Butt AS, Nisar N, Mughal TA, Ghani N, and Altaf I. 2019. Anti-oxidative and anti-proliferative activities of extracted phytochemical compound thymoquinone. J Pak Med Assoc 69:1479. https://doi.org/10.5455/JPMA.302643156

Callaway J. 2004. Hempseed as a nutritional resource: An overview. Euphytica 140:65-72. https://doi.org/10.1007/s10681-004-4811-6

Cowley JM, Herliana L, Neumann KA, Ciani S, Cerne V, and Burton RA. 2020. A small-scale fractionation pipeline for rapid analysis of seed mucilage characteristics. Plant Methods 16:20. https://doi.org/10.1186/s13007-020-00569-6

Dudonne S, Vitrac X, Coutiere P, Woillez M, and Merillon J-M. 2009. Comparative study of antioxidant properties and total phenolic content of 30 plant extracts of industrial interest using DPPH, ABTS, FRAP, SOD, and ORAC assays. Journal of agricultural and food chemistry 57:1768-1774. https://doi.org/10.1021/jf803011r

Farinon B, Molinari R, Costantini L, and Merendino N. 2020. The seed of industrial hemp (Cannabis sativa L.): Nutritional quality and potential functionality for human health and nutrition. Nutrients 12:1935. https://doi.org/10.3390/nu12071935

Folch J, Lees M, and Sloane Stanley GH. 1957. A simple method for the isolation and purification of total lipides from animal tissues. J Biol Chem 226:497-509.

Glahn RP, Lee OA, Yeung A, Goldman MI, and Miller DD. 1998. Caco-2 Cell Ferritin Formation Predicts Nonradiolabeled Food Iron Availability in an In Vitro Digestion/Caco-2 Cell Culture Model. J Nutr 128:1555-1561. https://doi.org/10.1093/jn/128.9.1555

Goyal A, Sharma V, Upadhyay N, Gill S, and Sihag M. 2014. Flax and flaxseed oil: an ancient medicine \& modern functional food. J Food Sci Technol 51:1633-1653. https://doi.org/10.1007/s13197-013-1247-9

Guo S, Ge Y, and Na Jom K. 2017. A review of phytochemistry, metabolite changes, and medicinal uses of the common sunflower seed and sprouts (Helianthus annuus L.). Chem Cent J 11:95. https://doi.org/10.1186/s13065-017-0328-7

Hassan AS, Houston K, Lahnstein J, Shirley N, Schwerdt JG, Gidley MJ, Waugh R, Little A, and Burton RA. 2017. A Genome Wide Association Study of arabinoxylan content in 2-row spring barley grain. PLOS ONE 12:e0182537. https://doi.org/10.1371/journal.pone.0182537 
428

429

430

431

432

433

434

435

436

437

438

439

440

441

442

443

444

445

446

447

448

449

450

451

452

453

454

455

456

457

458

459

460

461

462

463

464

465

466

467

468

469

470

471

472

473

474

475

476

477

Hofstee P, Bartho LA, McKeating DR, Radenkovic F, McEnroe G, Fisher JJ, Holland OJ, Vanderlelie JJ, Perkins AV, and Cuffe JSM. 2019. Maternal selenium deficiency during pregnancy in mice increases thyroid hormone concentrations, alters placental function and reduces fetal growth. J Physiol 597:5597-5617. https://doi.org/10.1113/JP278473

Ixtaina VY, Martínez ML, Spotorno V, Mateo CM, Maestri DM, Diehl BWK, Nolasco SM, and Tomás MC. 2011. Characterization of chia seed oils obtained by pressing and solvent extraction. J Food Compos Anal 24:166-174. https://doi.org/10.1016/j.jfca.2010.08.006

Knight JA. 2000. Free radicals, antioxidants, and the immune system. Ann Clin Lab Sci 30:145158.

Kumar P, Nagarajan A, and Uchil PD. 2018. Analysis of cell viability by the MTT assay. Cold Spring Harb Protoc 2018:pdb. prot095505. https://doi.org/10.1101/pdb.prot095505

Lin K-Y, Daniel JR, and Whistler RL. 1994. Structure of chia seed polysaccharide exudate. Carbohydr Polym 23:13-18. https://doi.org/10.1016/0144-8617(94)90085-X

Liu G, Mühlhäusler BS, and Gibson RA. 2014. A method for long term stabilisation of long chain polyunsaturated fatty acids in dried blood spots and its clinical application.

Prostaglandins Leukot Essent Fatty Acids 91:251-260.

https://doi.org/10.1016/j.plefa.2014.09.009

Marineli Rda S, Moura CS, Moraes EA, Lenquiste SA, Lollo PC, Morato PN, Amaya-Farfan J, and Marostica MR, Jr. 2015. Chia (Salvia hispanica L.) enhances HSP, PGC-1alpha expressions and improves glucose tolerance in diet-induced obese rats. Nutrition 31:740-748. https://doi.org/10.1016/j.nut.2014.11.009

Maritim A, Sanders a, and Watkins lii J. 2003. Diabetes, oxidative stress, and antioxidants: a review. J Biochem Mol Toxicol 17:24-38. https://doi.org/10.1002/jbt.10058

McKeating DR, Fisher JJ, Zhang P, Bennett WW, and Perkins AV. 2020. Elemental metabolomics in human cord blood: Method validation and trace element quantification. J Trace Elem Med Biol 59:126419. https://doi.org/10.1016/j.jtemb.2019.126419

Minekus M, Alminger M, Alvito P, Ballance S, Bohn T, Bourlieu C, Carriere F, Boutrou R, Corredig M, Dupont D, Dufour C, Egger L, Golding M, Karakaya S, Kirkhus B, Le Feunteun S, Lesmes U, Macierzanka A, Mackie A, Marze S, McClements DJ, Menard O, Recio I, Santos CN, Singh RP, Vegarud GE, Wickham MS, Weitschies W, and Brodkorb A. 2014. A standardised static in vitro digestion method suitable for food - an international consensus. Food Funct 5:1113-1124. 10.1039/c3fo60702j

Mohamed DA, Mohamed RS, and Fouda K. 2020. Anti-inflammatory potential of chia seeds oil and mucilage against adjuvant-induced arthritis in obese and non-obese rats. $J$ Basic Clin Physiol Pharmacol. https://doi.org/10.1515/jbcpp-2019-0236

Naran R, Chen G, and Carpita NC. 2008. Novel rhamnogalacturonan I and arabinoxylan polysaccharides of flax seed mucilage. Plant Physiol 148:132-141. https://doi.org/10.1104/pp.108.123513

Oude Groeniger J, van Lenthe FJ, Beenackers MA, and Kamphuis CB. 2017. Does social distinction contribute to socioeconomic inequalities in diet: the case of 'superfoods' consumption. Int J Behav Nutr Phys Act 14:40. 10.1186/s12966-017-0495-x

Pettolino FA, Walsh C, Fincher GB, and Bacic A. 2012. Determining the polysaccharide composition of plant cell walls. Nat Protoc 7:1590-1607. https://doi.org/10.1038/nprot.2012.081

Ponce de Leon-Rodriguez MDC, Guyot JP, and Laurent-Babot C. 2019. Intestinal in vitro cell culture models and their potential to study the effect of food components on intestinal inflammation. Crit Rev Food Sci Nutr 59:3648-3666. 10.1080/10408398.2018.1506734

Proestos C. 2018. Superfoods: Recent Data on their Role in the Prevention of Diseases. Current Research in Nutrition and Food Science 6:576-593. https://doi.org/10.12944/Crnfsj.6.3.02

PeerJ reviewing PDF | (2021:05:61800:2:0:NEW 20 Oct 2021) 
478

479

480

481

482

483

484

485

486

487

488

489

490

491

492

493

494

495

496

497

498

499

500

501

502

503

504

505

506

507

508
Saeman JF. 1945. Kinetics of Wood Saccharification - Hydrolysis of Cellulose and Decomposition of Sugars in Dilute Acid at High Temperature. Industrial and Engineering Chemistry 37:43-52. https://doi.org/10.1021/ie50421a009

Sambruy Y, Ferruzza S, Ranaldi G, and De Angelis I. 2001. Intestinal cell culture models: applications in toxicology and pharmacology. Cell Biol Toxicol 17:301-317. 10.1023/a:1012533316609

Santana AL, and Macedo GA. 2019. Effects of hydroalcoholic and enzyme-assisted extraction processes on the recovery of catechins and methylxanthines from crude and waste seeds of guarana (Paullinia cupana). Food Chem 281:222-230. https://doi.org/10.1016/j.foodchem.2018.12.091

Shah P, and Modi H. 2015. Comparative study of DPPH, ABTS and FRAP assays for determination of antioxidant activity. Int J Res App/ Sci Eng Technol 3:636-641.

Skorkowska-Telichowska K, Hasiewicz-Derkacz K, Gebarowski T, Kulma A, Moreira H, Kostyn K, Gebczak K, Szyjka A, Wojtasik W, and Gasiorowski K. 2016. Emulsions Made of Oils from Seeds of GM Flax Protect V79 Cells against Oxidative Stress. Oxid Med Cell Longev 2016:7510759. https://doi.org/10.1155/2016/7510759

Takahashi M, Higuchi M, Matsuki H, Yoshita M, Ohsawa T, Oie M, and Fujii M. 2013. Stress granules inhibit apoptosis by reducing reactive oxygen species production. Mol Cell Biol 33:815-829. https://doi.org/10.1128/MCB.00763-12

van den Driessche JJ, Plat J, and Mensink RP. 2018. Effects of superfoods on risk factors of metabolic syndrome: a systematic review of human intervention trials. Food Funct 9:1944-1966. https://doi.org/10.1039/C7FO01792H

Xu D, Murakoshi N, Igarashi M, Hirayama A, Ito Y, Seo Y, Tada H, and Aonuma K. 2012. PPAR-gamma activator pioglitazone prevents age-related atrial fibrillation susceptibility by improving antioxidant capacity and reducing apoptosis in a rat model. $J$ Cardiovasc Electrophysiol 23:209-217. https://doi.org/10.1111/j.1540-8167.2011.02186.x

Zimmer TBR, Otero DM, Pedra NS, Bona NP, Zarnott L, Spanevello RM, Gandra EA, and Zambiazi RC. 2021. Biological potential of hydroalcoholic extracts of Physalis pubescens L. Biocatalysis and Agricultural Biotechnology 31:101895. https://doi.org/10.1016/j.bcab.2020.101895 


\section{Table 1 (on next page)}

Seed flour nutrient composition with information provided on the packaging by commercial manufacturer and from independent testing. 


\begin{tabular}{|c|c|c|c|c|c|}
\hline & $\begin{array}{c}\text { Flax Seed } \\
\text { Linum usitatissimum }\end{array}$ & $\begin{array}{c}\text { Chia Seed } \\
\text { Salvia hispanica }\end{array}$ & $\begin{array}{c}\text { Sunflower Seed } \\
\text { Helianthus annuus }\end{array}$ & \multicolumn{2}{|c|}{ Cannabis sativa } \\
\hline \multicolumn{6}{|l|}{$\begin{array}{r}\text { Seed Nutrient Composition provided } \\
\text { on packaging (per 100g) }\end{array}$} \\
\hline Energy $(\mathrm{kJ} / 100 \mathrm{~g})$ & 2172 & 2100 & 2755 & 2599 & 1680 \\
\hline Protein (\%) & 21 & 21 & 21 & 31.3 & 17 \\
\hline Carbohydrate (\%) & $<1$ & 37 & 7.2 & 2 & 6.7 \\
\hline Dietary Fibre (\%) & 28.8 & 35 & 8.8 & 3.3 & 67.1 \\
\hline Fat $(\%)$ & 43 & 29 & 57 & 54.2 & 8.9 \\
\hline \multicolumn{6}{|l|}{ Fatty Acid Composition of Seed Oil } \\
\hline $\begin{array}{r}\text { Saturated Fatty } \\
\text { Acids }\end{array}$ & 10.8 & 11.8 & 11.9 & 10.8 & 12.7 \\
\hline Myristic Acid (14:0) (\%) & 0.0 & 0.0 & 0.1 & 0.1 & 0.0 \\
\hline Pentadecylic Acid (15:0) (\%) & 0.0 & 0.0 & 0.0 & 0.0 & 0.0 \\
\hline Palmitic Acid (16:0) (\%) & 5.9 & 7.6 & 6.8 & 6.3 & 8.0 \\
\hline Margaric Acid (17:0) (\%) & 0.1 & 0.1 & 0.0 & 0.1 & 0.1 \\
\hline Stearic Acid (18:0) (\%) & 4.3 & 3.5 & 3.8 & 3.3 & 3.3 \\
\hline Arachidic Acid (20:0) (\%) & 0.2 & 0.3 & 0.3 & 0.7 & 0.8 \\
\hline Behenic Acid (22:0) (\%) & 0.1 & 0.1 & 0,7 & 0.2 & 0.3 \\
\hline Lignoceric Acid (24:0) (\%) & 0.1 & 0.1 & 0.3 & 0.1 & 0.2 \\
\hline \begin{tabular}{r|r|} 
Unsaturated Fatty & Total (\%) \\
Acids &
\end{tabular} & 89.2 & 88.2 & 88.1 & 89.2 & 87.3 \\
\hline Total $(\%)$ & 56.4 & 61.3 & 0.1 & 14.5 & 15.7 \\
\hline Alpha-Linolenic Acid (18:3 n-3) (\%) & 56.4 & 61.3 & 0.1 & 14.5 & 15.7 \\
\hline \begin{tabular}{r|r|}
$\omega-6$ & Total $(\%)$
\end{tabular} & 14.7 & 19.9 & 61.4 & 58.4 & 57.7 \\
\hline Linoleic Acid (18:2 n-6) (\%) & 14.7 & 19.8 & 61.4 & 57.9 & 57.3 \\
\hline Eicosadienoic Acid (20:2 n-6) (\%) & 0.0 & 0.1 & 0.0 & 0.1 & 0.0 \\
\hline \begin{tabular}{c|c}
$\omega-7$ & Total $(\%)$
\end{tabular} & 1.0 & 0.9 & 0.8 & 0.8 & 0.9 \\
\hline Palmitoleic Acid (16:1 n-7) (\%) & 0.1 & 0.1 & 0.1 & 0.1 & 0.1 \\
\hline Vaccenic Acid (18:1 n-7) (\%) & 0.9 & 0.9 & 0.7 & 0.7 & 0.8 \\
\hline \begin{tabular}{c|c}
$\omega-9$ & Total $(\%)$
\end{tabular} & 17.1 & 6.0 & 25.8 & 15.4 & 12.9 \\
\hline Oleic Acid (18:1 n-9) (\%) & 17.0 & 5.9 & 25.7 & 15.1 & 12.4 \\
\hline Gondoic Acid (20:1 n-9) (\%) & 0.1 & 0.1 & 0.1 & 0.4 & 0.4 \\
\hline \begin{tabular}{l|l|}
$\omega-3: \omega-6$ & Actual Ratio(n:1)
\end{tabular} & 3.837 & 3.084 & 0.002 & 0.249 & 0.272 \\
\hline Representative Ratio & $11: 3$ & $3: 1$ & $1: 614$ & $1: 4$ & $2: 7$ \\
\hline \multicolumn{6}{|l|}{ Mineral Composition } \\
\hline $\mathrm{Na}(\mathrm{mg} / \mathrm{kg})$ & 1073 & 0 & 0 & 0 & 0 \\
\hline$M g(m g / k g)$ & 4425 & 3525 & 3493 & 5359 & 3296 \\
\hline$K(m g / k g)$ & 7482 & 7679 & 7930 & 9747 & 7367 \\
\hline $\mathrm{Ca}(\mathrm{mg} / \mathrm{kg})$ & 1388 & 5689 & 1289 & 349 & 982 \\
\hline $\mathrm{Cr}(\mathrm{mg} / \mathrm{kg})$ & 2 & 2 & 1.5 & 2 & 1.3 \\
\hline$M n(m g / k g)$ & 23.3 & 30.6 & 31.5 & 68 & 91.5 \\
\hline $\mathrm{Fe}(\mathrm{mg} / \mathrm{kg})$ & 143 & 145.4 & 80.6 & 196 & 196.3 \\
\hline $\operatorname{Co}(\mathrm{mg} / \mathrm{kg})$ & 0.9 & 0.3 & 0.1 & 0.1 & 0.1 \\
\hline$N i(m g / k g)$ & 1.2 & 1.8 & 5.2 & 53.2 & 0.6 \\
\hline $\mathrm{Cu}(\mathrm{mg} / \mathrm{kg})$ & 17.4 & 17.7 & 24.2 & 12.2 & 14.1 \\
\hline $\mathrm{Zn}(\mathrm{mg} / \mathrm{kg})$ & 43.7 & 52.0 & 66.1 & 81.7 & 53.0 \\
\hline $\mathrm{Se}(\mathrm{mg} / \mathrm{kg})$ & 0.9 & 0.9 & 0 & 1.8 & 1.0 \\
\hline Mo $(\mathrm{mg} / \mathrm{kg})$ & 0.2 & 0.7 & 0.3 & 1.1 & 0.6 \\
\hline$I(\mathrm{mg} / \mathrm{kg})$ & 274.4 & 267.6 & 403.7 & 459.4 & 314.7 \\
\hline
\end{tabular}




\section{Figure 1}

Figure 1. Diagram of crude aqueous extract preparation.

Figure 1. Diagram of crude aqueous extract preparation. A. Some seeds require processing to remove inedible components like the husk. Flax and chia seeds are consumed unprocessed, while sunflower and hemp seeds are commonly consumed as kernels $(k)$ where the indigestible hull/husk ( $h$ ) is removed (hulled sunflower and hulled hemp). Hemp is also consumed as a flour where oil and crude protein have been extracted for other products (hemp flour). B. These forms of the seeds are the most commonly consumed and were the starting material for extraction. C. Except hemp flour, seeds were ground (gr) to flour. D. $4 \mathrm{~g}$ of seed flour was extracted in body temperature $\left(37^{\circ} \mathrm{C}\right)$ water for 3 hours with intense agitation. E. Debris was pelleted by centrifugation and the aqueous extracts were decanted and dried. F. Dried extracts were weighed and compared against the starting material to determine the aqueous extract yield. 


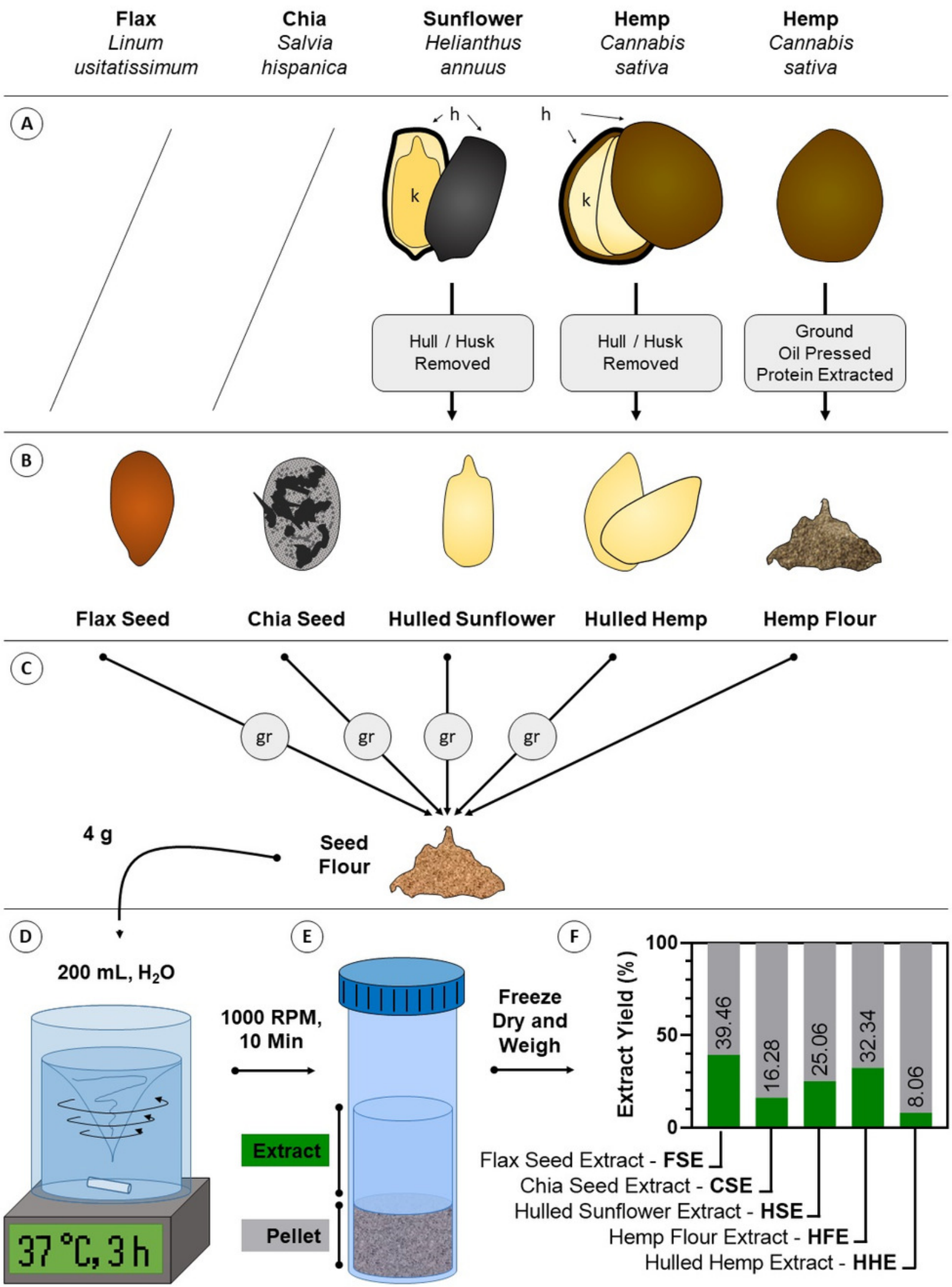


Figure 2

Viability of Caco-2 cells after treatment with flax, chia, sunflower, and hemp crude aqueous extracts.

(A) Plotted dose-response models. (B) Table of mean viability estimated from the doseresponse model. Bold values are statistically significant when compared to the vehicle control $(p<0.05) .{ }^{a}$ Estimated mean $\pm S E M,{ }^{b} p$-value of model contrasts comparing viability in a treatment to the control. Purple ribbon represents standard error, red line is estimated mean. 
A
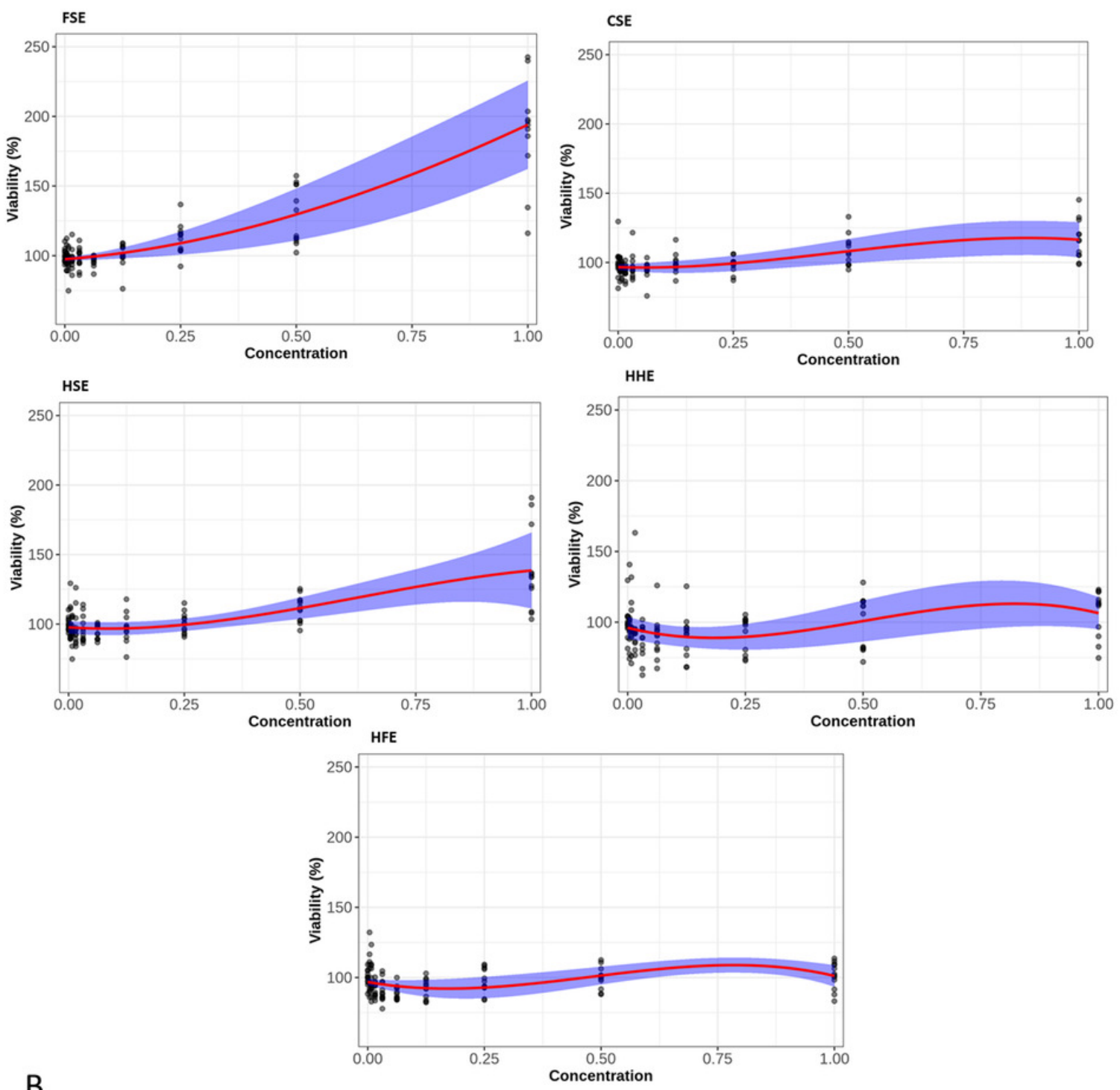

B

$\begin{array}{ccccc}\text { Flax Seed } & \text { Chia Seed } & \text { Hulled } & \text { Hulled Hemp } & \text { Hemp Flour } \\ \text { Extract } & \text { Extract } & \begin{array}{c}\text { Sunflower } \\ \text { Extract }\end{array} & \begin{array}{c}\text { Extract } \\ \text { Extract }\end{array} & \text {. }\end{array}$

\begin{tabular}{llllll}
\hline Control, $0 \mathrm{mg} / \mathrm{mL}$ & $100.00 \pm 0.00$ & $100.00 \pm 0.00$ & $100.00 \pm 0.00$ & $100.00 \pm 0.00$ & $100.00 \pm 0.00$ \\
$0.625 \mathrm{mg} / \mathrm{mL}$ & $96.71 \pm 1.21$ & $94.60 \pm 2.29$ & $94.59 \pm 1.27$ & $89.71 \pm 4.79$ & $88.90 \pm 2.04$ \\
& 0.01 & 0.02 & $<0.001$ & 0.03 & 9.001 \\
$0.125 \mathrm{mg} / \mathrm{mL}$ & $100.47 \pm 2.29$ & $99.27 \pm 2.80$ & $97.26 \pm 2.80$ & $90.35 \pm 3.71$ & 0.01 \\
& 0.84 & 0.79 & 0.33 & 0.01 & $97.38 \pm 3.73$ \\
$0.25 \mathrm{mg} / \mathrm{mL}$ & $111.83 \pm 4.25$ & $98.46 \pm 1.99$ & $100.78 \pm 2.47$ & $92.05 \pm 3.61$ & 0.48 \\
$0.5 \mathrm{mg} / \mathrm{mL}$ & 0.01 & 0.44 & 0.75 & 0.03 & $99.89 \pm 3.24$ \\
& $128.79 \pm 9.37$ & $108.27 \pm 4.74$ & $111.02 \pm 3.89$ & $99.89 \pm 7.66$ & 0.97 \\
$1 \mathrm{mg} / \mathrm{mL}$ & 0.01 & 0.08 & 0.01 & 0.99 & $101.27 \pm 3.89$ \\
\hline
\end{tabular}


Figure 3

Viability of IEC- 6 cells after treatment with flax, chia, sunflower, and hemp crude aqueous extracts

(A) Plotted dose-response models. (B) Table of mean viability estimated from the doseresponse model. Bold values are statistically significant when compared to the vehicle control $(p<0.05)$. ${ }^{a}$ Estimated mean $\pm S E M,{ }^{b} p$-value of model contrasts comparing viability in a treatment to the control. Purple ribbon represents standard error, red line is estimated mean. 
A
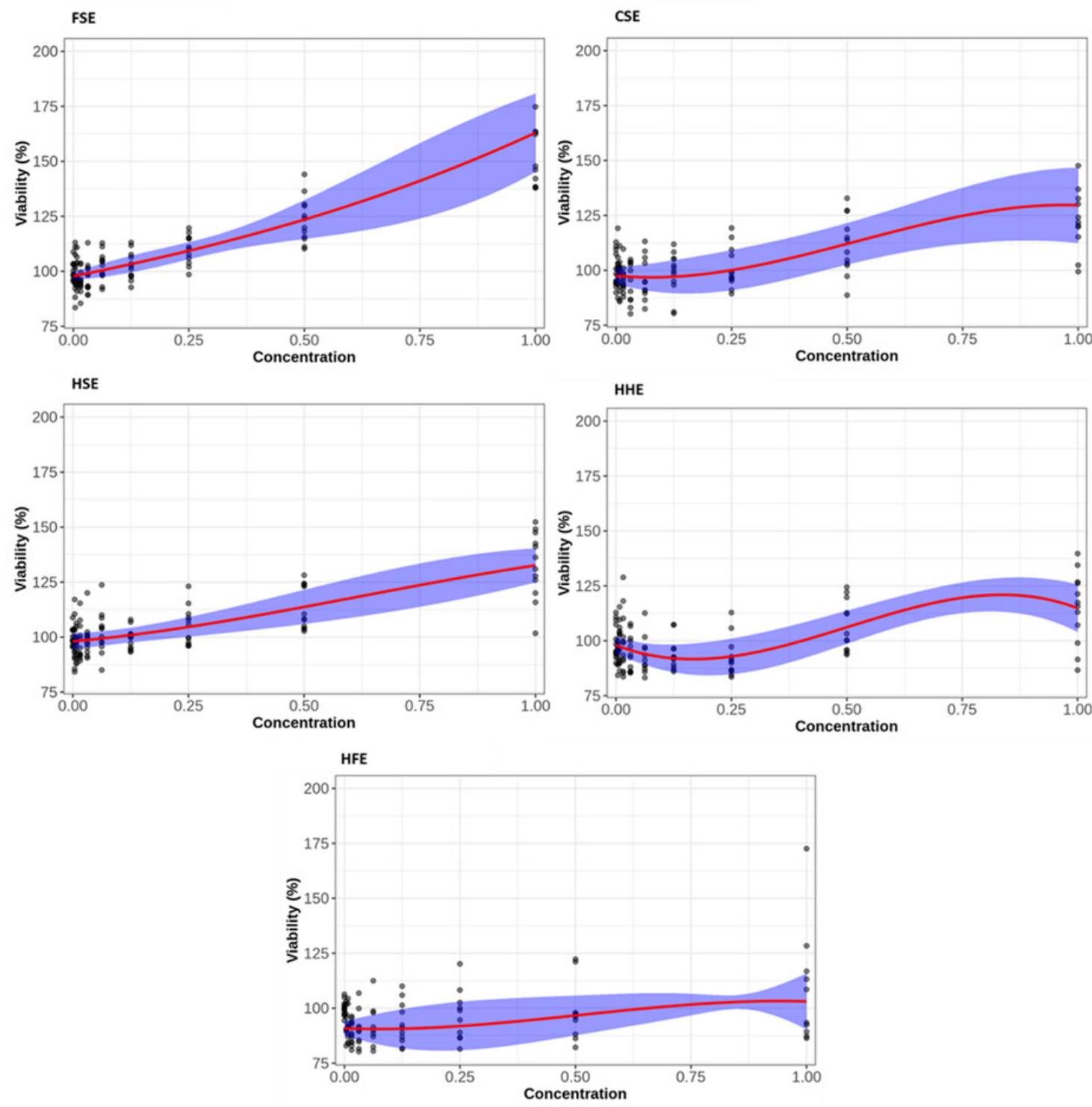

B

\begin{tabular}{|c|c|c|c|c|c|}
\hline & $\begin{array}{c}\text { Flax Seed } \\
\text { Extract }\end{array}$ & $\begin{array}{c}\text { Chia Seed } \\
\text { Extract }\end{array}$ & $\begin{array}{c}\text { Hulled } \\
\text { Sunflower } \\
\text { Extract }\end{array}$ & $\begin{array}{c}\text { Hulled Hemp } \\
\text { Extract }\end{array}$ & $\begin{array}{c}\text { Hemp Flour } \\
\text { Extract }\end{array}$ \\
\hline Control, $0 \mathrm{mg} / \mathrm{mL}$ & $100.00 \pm 0.00$ & $100.00 \pm 0.00$ & $100.00 \pm 0.00$ & $100.00 \pm 0.00$ & $100.00 \pm 0.00$ \\
\hline $0.625 \mathrm{mg} / \mathrm{mL}$ & $\begin{array}{l}102.37 \pm 1.47 \\
0.11\end{array}$ & $\begin{array}{l}94.98 \pm 4.77 \\
0.29\end{array}$ & $\begin{array}{l}102.04 \pm 2.77 \\
0.46\end{array}$ & $\begin{array}{l}92.07 \pm 3.39 \\
0.02\end{array}$ & $\begin{array}{l}88.24 \pm 3.72 \\
0.01\end{array}$ \\
\hline $0.125 \mathrm{mg} / \mathrm{mL}$ & $\begin{array}{l}102.35 \pm 1.98 \\
0.24\end{array}$ & $\begin{array}{l}98.49 \pm 3.14 \\
0.63\end{array}$ & $\begin{array}{l}99.34 \pm 1.44 \\
0.64\end{array}$ & $\begin{array}{l}93.82 \pm 2.98 \\
0.04\end{array}$ & $\begin{array}{l}91.58 \pm 4.42 \\
0.06\end{array}$ \\
\hline $0.25 \mathrm{mg} / \mathrm{mL}$ & $\begin{array}{l}110.13 \pm 2.39 \\
<0.001\end{array}$ & $\begin{array}{l}101.13 \pm 3.93 \\
0.77\end{array}$ & $\begin{array}{l}104.70 \pm 2.23 \\
0.04\end{array}$ & $\begin{array}{l}92.34 \pm 3.81 \\
0.04\end{array}$ & $\begin{array}{l}93.59 \pm 538 \\
0.23\end{array}$ \\
\hline $0.5 \mathrm{mg} / \mathrm{mL}$ & $\begin{array}{l}123.3 \pm 4.37 \\
<0.001\end{array}$ & $\begin{array}{l}111.57 \pm 5.14 \\
0.02\end{array}$ & $\begin{array}{l}113.74 \pm 3.98 \\
<0.001\end{array}$ & $\begin{array}{l}106.19 \pm 3.91 \\
0.11\end{array}$ & $\begin{array}{l}96.03 \pm 4.57 \\
0.38\end{array}$ \\
\hline $1 \mathrm{mg} / \mathrm{mL}$ & $\begin{array}{l}163.00 \pm 8.98 \\
<0.001\end{array}$ & $\begin{array}{l}129.64 \pm 8.65 \\
<0.001\end{array}$ & $\begin{array}{l}132.57 \pm 3.92 \\
<0.001\end{array}$ & $\begin{array}{l}114.88 \pm 5.49 \\
0.01\end{array}$ & $\begin{array}{l}103.12 \pm 6.42 \\
0.63\end{array}$ \\
\hline
\end{tabular}


Figure 4

Summary of aqueous extract composition.

(A) Protein concentration, aqueous extract monosaccharide and mineral profiles. (B) Stacked graph summarising the quantified components in the aqueous extracts. 
A

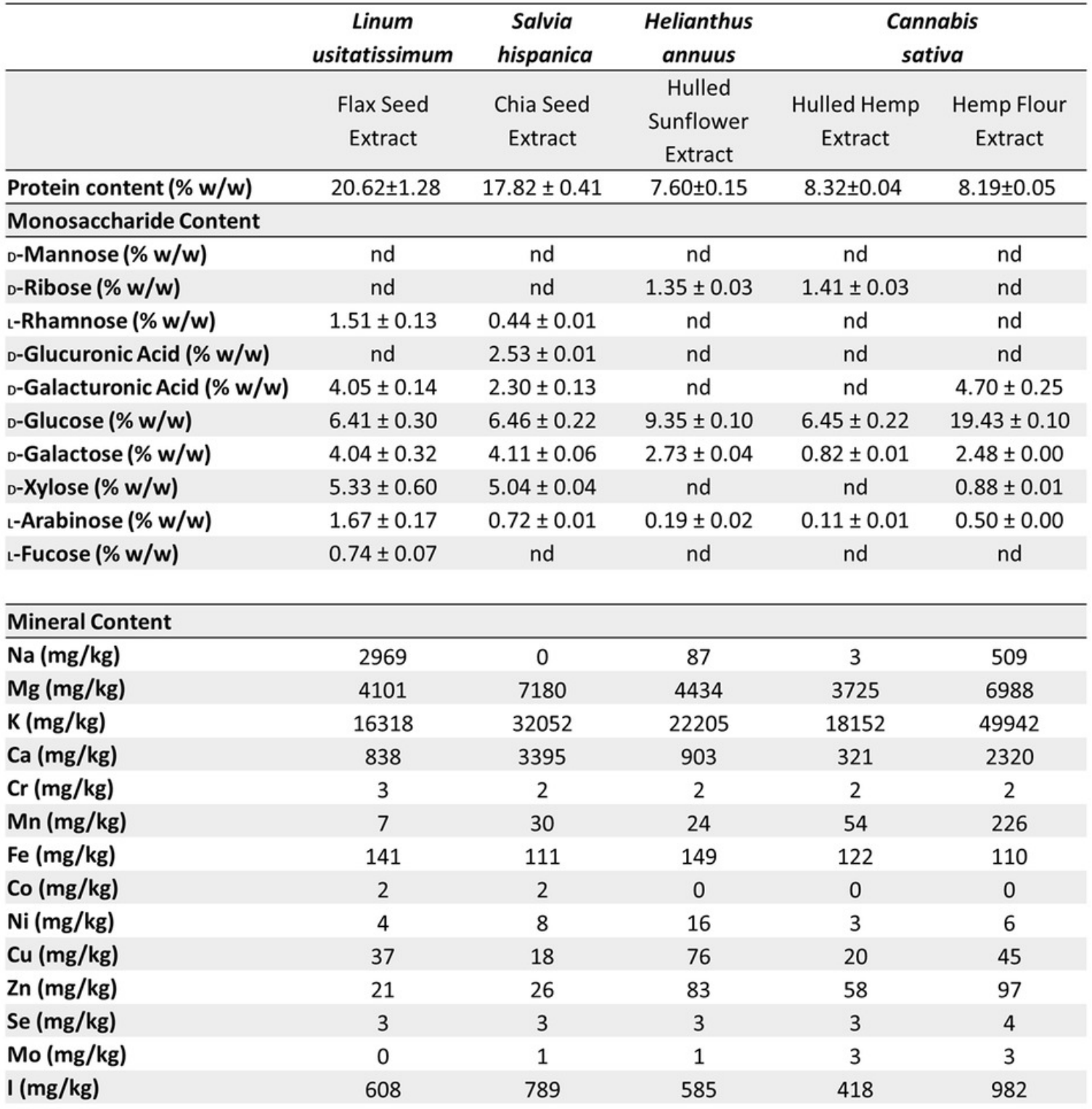

B

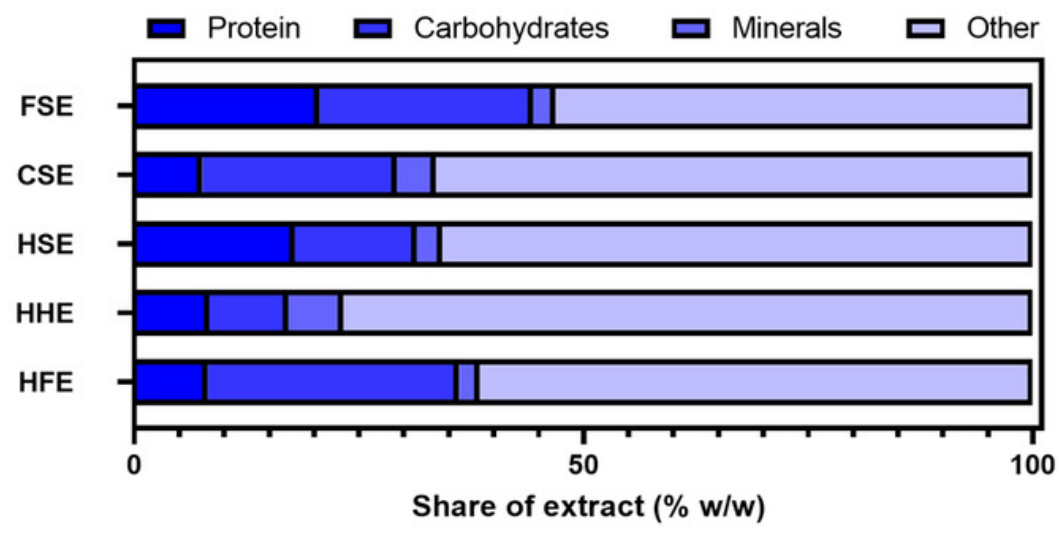




\section{Figure 5}

Mineral profiling comparing aqueous extracts to their source flour.

(A) Change in absolute mineral concentration from source flour to aqueous extracts. (B)

Extractability of minerals from sunflower, flax, chia, and hemp seed flour represented as the percentage from whole seed found in the aqueous extracts. White cells are values greater than $100 \%$ extractability. Crossed values are unable to be calculated due to zero values (below quantitation limit). 
A
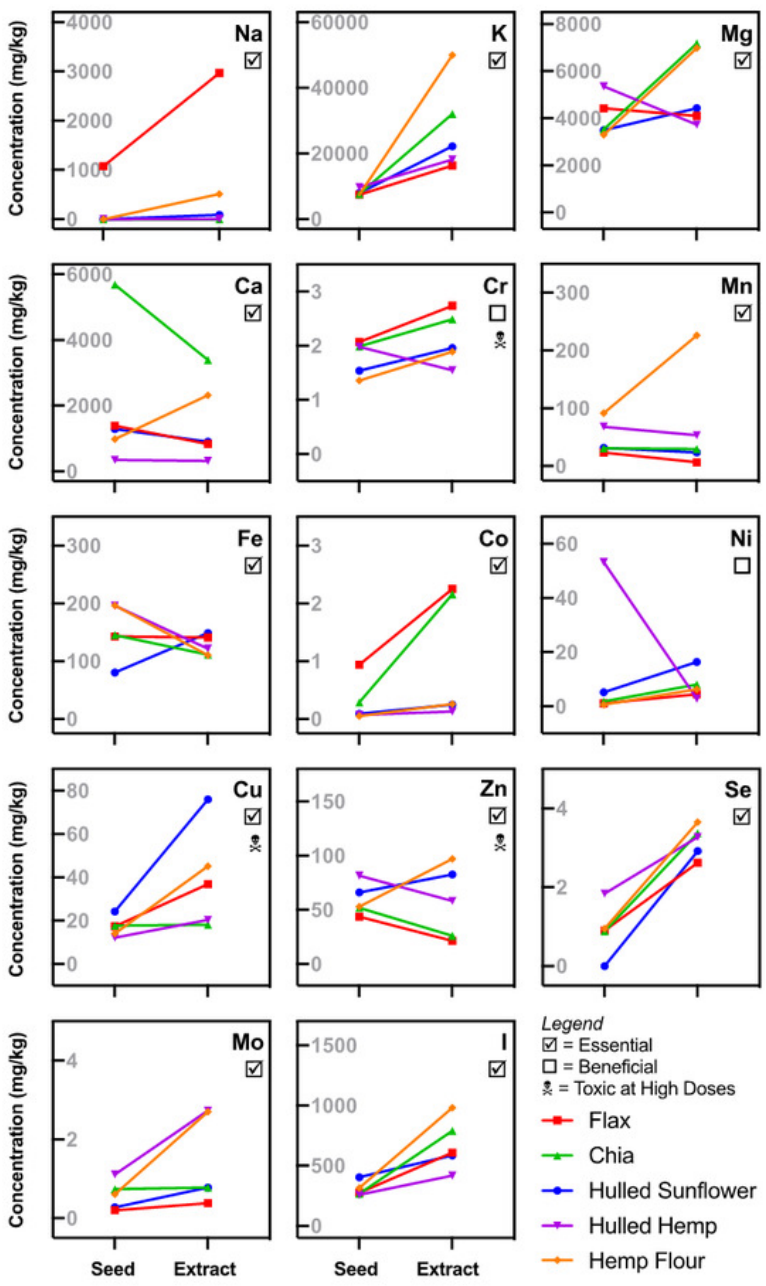

Legend
$\square=$ Essential

$\square=$ Beneficial

$\varepsilon=$ Toxic at High Doses

$\rightarrow$ Flax

- Chia

$\rightarrow$ Hulled Sunflower

- Hulled Hemp

B

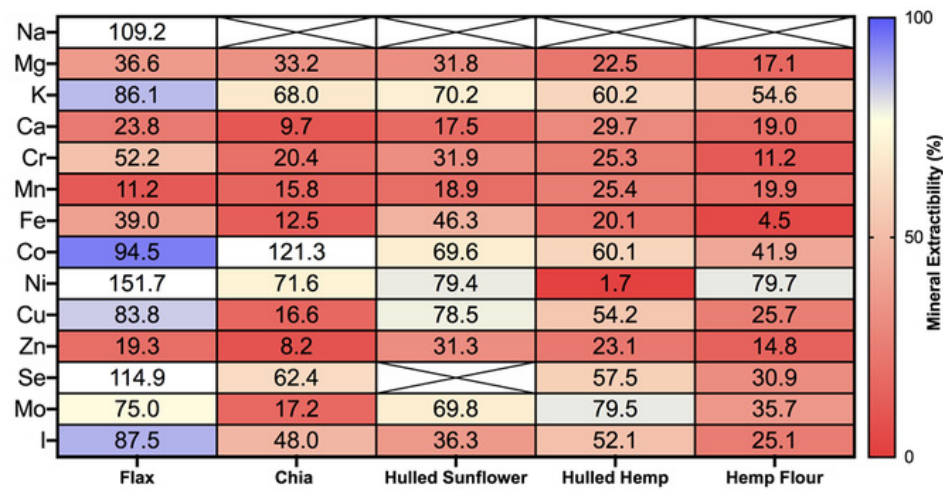

